\title{
MENATA RUMAH YANG ISLAMI
}

\author{
${ }^{1}$ Hafidz Zamroni Zien \\ ${ }^{2}$ Tarranita Kusumadewi \\ Jurusan Arsitektur,Fakultas Sains dan Teknologi UIN Maliki Malang, Jl. \\ Gajayana 50 Malang, email. Hafidz_archi@yahoo.com 08990397762, \\ tarra_nita@yahoo.com 08155206293
}

\begin{abstract}
Prophet Muhammad in a hadith reveals that there are four things making people happy: having shalihah wife, spacious houses, comfortable vehicles, and good neighbors. A house as the inhabited buildings working as the activity base is one of the ways to form a society and Islam civilization. An Islamic house must be able to have two functions in life. First, the welfare of the world including: a sense of compassion (mawadah warahmah), ensuring children's education, creating hospitality (ukhuwah Islamiyah), forming the Muslim individual, supporting successful careers, and having health condition. Second, the welfare of the afterlife including: easy to implement the mahdah worship, muamalah process and able to keep its inhabitants from the things forbidden and makruh.

An Islamic house is not always designed like mosques or houses which are full of Islamic ornaments, such as calligraphy, and more. An Islamic house is an efficient house which can be used to dhikr to Allah, and to remember death. The house is not always facing the Qibla or the lavatory was not facing Mecca. An Islamic house is a house that allows occupants to stay and interact with others. Besides, the privacy of each person can also be maintained in it. It is then becoming the task of the architects to make Islamic houses. However, the most important thing of an Islamic house is that it does not isolate the occupants from the outside world. Further, it could create a better interaction and social relationship with its surroundings and neighbors.
\end{abstract}

Key words: Islamic House, rules, adab

Nabi Muhammad dalam sebuah hadits mengungkapkan bahwa ada empat
halmembuat orang bahagia: memiliki istri shalihah, rumah yang
luas, kendaraanyang nyaman, dan tetangga yang baik. Sebuah
rumah sebagai bangunan dihuni sebagai basis kegiatan yang juga merupakan salah
satu cara untuk membentuk masyarakat dan peradaban Islam. Sebuah rumah yang
islami memiliki dua fungsi dalam kehidupan. Pertama, menyediakan
kesejahteraan dunia
sayang (mawadah warahmah), menjamin pendidikan mantaranya rasa kasih
anak, menjamin kesehatan (ukhuwah Islamiyah), membentuk individu muslim,
mendukung karier, dan kesehatan.Kedua, kesejahteraan akhirat termasuk: mudah
untuk melaksanakan ibadah mahdah, melaksanakan muamalah dan mampu
menjaga penghuninya dari hal yang dilarang dan makruh.


Sebuah rumah yang Islami tidak selalu dirancang seperti masjid atau rumah yang penuh dengan ornamen Islam, seperti kaligrafi, dan banyak lagi. Sebuah rumah yang Islami adalah sebuah rumah yang efisien yang dapat digunakan untuk berdzikir kepada Allah, dan selalu mengingat pada kematian. Sebuah rumah yang Islami adalah sebuah rumah yang memungkinkan penghuni untuk tinggal dan berinteraksi dengan orang lain. Selain itu, privasi setiap orang juga dapat dipertahankan di dalamnya. Hal ini kemudian menjadi tugas arsitek untuk membuat rumah yang Islami.Namun, hal yang paling penting dari sebuah rumah yang Islami adalah bahwa rumah tersebut tidak mengisolasi penghuni dari dunia luar. Selanjutnya, bisa membuat interaksi yang lebih baik dan hubungan sosial dengan tetangga dan lingkungannya.

\section{Latar Belakang}

'Rumah' bagi semua makhluk yang ada di muka bumi ini, baik manusia, hewan maupun tumbuhan, merupakan kebutuhan mendasar yang berfungsi sebagai tempat berlindung. Dalam manfaat yang lebih luas, rumah tidak hanya sebagai tempat berlindung, namun juga sebagai tempat bernaung dan memperoleh segala manfaat dengannya. Konteks rumah di dalam Islam juga dapat dimaknai sebagai tempat untuk beribadah kepada Allah SWT (Junara dan Putrie, 2009: 19). Terdapat beberapa istilah tentang rumah dalam Islam. Ada yang mengatakan bayt dan ada pula yang mengatakan dar. Keduanya merupakan istilah yang berasal dari bahasa Arab. Bayt memiliki salah satu makna sebagai tempat untuk melewati malam, atau tinggal pada siang hari. Sedangkan dar atau dara antara lain berarti mengelilingi, melaksanakan/melangsungkan, dan sebagainya (Omer, 2009, dalam Junara dan Putrie, 2009).

Dalam Islam, rumah merupakan tempat untuk beristirahat, menenangkan jiwa dan raga serta menikmati segala kebebasan yang terbatas dari dunia luar. Rumah juga dipenuhi oleh privasi, perlindungan dan keamanan, dengan segala fasilitas di dalamnya. Selain itu di dalam rumah juga terjadi interaksi dan pembelajaran sebagaimana yang dituliskan dalam islam (Omer, 2009: 163).

Rumah merupakan bagian terkecil dari suatu lingkungan yang tercipta dari berbagai komunitas lingkungan lainnya. Ini berarti rumah tidak dapat berdiri sendiri namun juga berinteraksi dengan rumah lainnya dalam bentuk hubungan bertetangga membentuk suatu lingkungan yang lebih besar. Selanjutnya, rumah yang akan dibangun hendaknya memiliki adab yang terkait dengan urusan di dalam rumah itu sendiri, maupun dalam bersikap dengan tetangga. Hal ini merupakan cerminan dalam Islam, dalam mengatur rumah bagi seorang muslim. Selanjutnya, pengetahuan seorang muslim akan adab dan aturan-aturan yang lslami dalam penataan rumahnya merupakan hal yang sangat penting bagi terciptanya rumah yang lslami.

Sudah banyak buku-buku yang telah menyinggung masalah rumah yang lslami, namun dalam skala pembicaraan yang umum, atau oleh sebab tertentu. Akan tetapi sangat sedikit sekali, tulisan-tulisan yang mengkaji secara mendalam namun ringkas, tentang pokok-pokok penting yang harus diperhatikan oleh seorang 
muslim dalam menata rumahnya. Risalah ini diharapkan menjadi suatu tadzkirah (peringatan), dan dapat memenuhi kebutuhan tersebut.

\section{Sejarah Rumah Tinggal pada masa Rasululllah SAW}

Rasulullah SAW membangun rumah ketika pertama kali tiba di Madinah sehabis hijrah. Diantara banyaknya penawaran, Rasulullah SAW menerima permintaan sebuah keluarga dari Bani Najjar yang memberikan tanah untuk ditinggali. Tanah ini dulunya adalah tempat mengeringkan korma dan kuburan orang-orang musyrik. Rasulullah SAW menyetujui dengan syarat tanah ini diratakan dan kuburan dipindahkan. Hal Ini memiliki arti bahwa tidak dibenarkan dalam Islam, adanya kuburan dalam rumah. Dalam segi konstruksi, rumah Rasulullah dibangun dari batu bata yang terbuat dari campuran tanah liat dengan serat gandum (barley) dan dikeringkan dengan panas matahari. Rumah Rasulullah berdinding bata, dilengkapi courtyard yang luas (open space di dalam bangunan), dan memiliki entrance di bagian utara dan selatan. Rumah dengan konsep housemosque tersebut memiliki tiga pintu. Ketika kiblat diubah dari Jerussalem ke Makkah, pintu selatan ditutup dan dijadikan dinding untuk arah kiblat. Kamarkamar rumah Rasulullah beratap pelepah kurma dengan luas tiap kamar sekitar 23 $\mathrm{m}^{2}$ dan tinggi plafon 2,7-3,6 m. Kamar-kamar bertambah dari 1-9 sesuai jumlah isteri-isteri Rasulullah. Ada kebiasan di zaman Rasulullah, bahwa jika hendak membangun pondasi rumah, maka para sahabat baik kaum Muhajirin dan Anshar diundang untuk bekerja bersama.

Ukuran rumah di Mesir pada era Fatimiyah di abad ke-10 dan 11 M, cukup besar bagi sebuah keluarga terdiri dari seorang suami, isteri dan anak. Ukuran rumah mengakomodasi keluarga inti dan juga dikembangkan jika ada perluasan keluarga (jika anak juga menikah dan berkeluarga). Mereka hidup di dalam satu bangunan atau satu kelompok bangunan dan membentuk neighborhood. Tidak ada pemisahan antara space pria dan wanita ketika era Fatimiyah. Kepemilikan rumah adalah kepemilikan bersama kadang-kadang keluarga menyewakan atau menjual salah satu bagian rumah untuk menjadi pendapatan tambahan (Campo, 1991).

Bahwa di zaman kekaisaran Ottoman Turki (1590-1700), rumah biasanya terdiri dari bangunan dan courtyard, tidak jarang juga dilengkapi dengan taman. Rumah tersebut memiliki "tabhane" (ruang utama) yang dipakai sebagai tempat menerima tamu. Karena cukup besar, ruangan ini kadang difungsikan sebagai living room. Selain itu rumah juga memiliki "sofa" (ruang terbuka atau tertutup) untuk hall penghubung antar kamar. Bangunan rumah pada masa itu terdiri dari dua lantai atau satu lantai dengan jumlah kamar 4-5 kamar, 1 courtyard, 2 toilet, dapur, sofa, ruang mencuci, dan ruang tamu (tabhane). Ukuran kamar biasanya sekitar 5-6 m panjang, 3-4 m, lebar, dan tinggi $3 \mathrm{~m}$. Ukuran ini merupakan ukuran standar bagi kebanyakan keluarga. Bagi mereka yang berpenghasilan tinggi, rumah tentu memiliki kamar lebih banyak dan ukuran lebih besar. Bahkan, rumah orang-orang kaya ini terdiri dari bagian-bagian rumah khusus wanita ("harem") dan "selamlik" khusus untuk tamu pria. Kadang-kadang memiliki 2 bangunan yang terpisah yang dihubungkan dengan courtyard atau sofa lengkap dengan 
berandah. Pada masa itu memiliki ciri khas yang sama yakni courtyard dan taman. Selain itu, patut pula dicatat bahwa bagi yang mempunyai kuda sebagai kendaraan dimasa itu, rumah dilengkapi dengan istal. Secara umum, dapat disimpulkan bahwa konsep rumah dalam peradaban Islam adalah rumah yang mempunyai banyak kamar, dan dilengkapi tabhane, taman, dan courtyard. Hal ini menegaskan bahwa keluarga dalam konsep Islam cenderung besar. Keluarga besar ini tentu membutuhkan privasi yang dapat dipenuhi ketersediaan kamar yang cukup. Kamar-kamar ini juga diperuntukkan bagi orang tua atau sanak keluarga yang datang bersilaturrahim (Campo, 1991).

Selain itu, konsep living room dan hall memberikan penghargaan bagi tamu yang datang, dan juga tempat berkumpulnya anggota keluarga. Sedangkan konsep courtyard di dalam rumah, ini bukan hanya bagus untuk ventilasi dan pencahayaan, namun juga menjadi arena rekreasional yang memungkinkan anakanak dan remaja muslimah bermain tanpa harus memakai hijab (dengan privasi), dan menjadi tempat berkontemplasi/bercengkerama dengan alam. Dalam mendesain rumah, Islam juga mengatur mengenai konsep silaturrahim dan konsep ummah, dimana manusia harus menjaga hubungan dengan lingkungan dan masyarakat sekitarnya. Oleh karena itu konsep rumah dalam Islam mempunyai space khusus untuk menerima tamu pada hari-hari raya dan untuk acara-acara keluarga. Hanya saja, ada semacam perjanjian tak tertulis bagi tamu dan penghuni rumah. Tamu memasuki rumah lewat pintu depan kemudian melalui koridor menuju courtyard bagian dalam. Koridor ini didesain sedemikian agar tidak mengganggu privasi penghuni rumah. Tamu kemudian duduk di berandah yang menghadap ke courtyard. Jika ada acara besar di rumah, tamu diundang ke semacam ruangan disekitar courtyard yang didesain lengkap dengan taman, kolam, dan air mancur yang menciptakan suasana yang nyaman bagi tamu dan tuan rumah (Faroqhi, 1987).

\section{Telaah Bangunan Arsitektur yang Islam}

Di dalam buku the Grand tradition of Islamic Architecture, menjelaskan bahwa arsitektur yang islam adalah arsitektur yang berlandaskan Qur'an dan Hadist Rasulullah SAW. Bangunan arsitektur tersebut harus sesuai dengan nilainilai (Rehman, 2002) :

$>$ Pertama adalah tauhid dan risalah. Bangunan didirikan tidak ada didalamnya unsur syirik dalam pembuatannya, desain dan ornamen di dalamnya (termasuk didalamnya penggunaan patung). Bangunan itu tidak dibuat dengan mengotori atau merusak alam, binatang dan tumbuhan. Oleh karena itu, hiasan dan ornamen interior dalam arsitektur Islam banyak menggunakan motif tumbuhan (arabesques), kaligrafi dan geometri.

$>$ Kedua, Qur'an memberikan kesadaran akan lingkungan dan realitas lingkungan. Diantaranya adalah struktur matematika dalam Qu'ran yang menghubungkan intelektual dan spiritual Islam dan matematika sebagaimana yang terkandung dalam struktur dari Qur'an sendiri dan simbol-simbol numeric dari huruf dan kata. Oleh karena itu, seni arsitektur Islam 
berkembang dalam konsep geometri, astronomi dan metafisik. Konsep ini dapat dilihat di QS 3:191.

> Ketiga, konsep desain berbasis geometri murni. Bangunan memiliki "badan" yang didesain dengan konsep geometri. Adapun jiwanya dapat didesain dengan memodifikasi pencahayaan, ventilasi, efek suara, landsekap, warna, tekstur, dan interior dan eksterior. Konsep ini bisa dilihat dari rumah-rumah, masjid, makam, atau taman.

$>$ Empat, konsep surga di Bumi. Dalam QS 2:82 dan 55:46-47, Allah SWT mendeskripsikan taman-taman surga. Arsitektur Islam sangat dipengaruhi dengan konsep taman dan courtyard sehingga landsekap menjadi bagian yang tak terpisahkan dari bangunan.

$>$ Kelima, konsep cahaya. Cahaya sebagai simbol spiritualitas dikenal dalam dunia sufi. Arsitektur Islam mendesain pencahayaan, bayang-bayang, panas dan dingin dari angin, air beserta efek pendinginnya, dan tanah. Tujuannya adalah agar komponen insulating ini harmonis dengan alam. Konsep dan nilai tersebut diatas merupakan framework dalam mendesain rumah yang memiliki nilai-nilai Islam dalam rangka beribadah kepada Allah SWT.

\section{Konsep Rumah Tinggal yang Islami}

Tempat tinggal sebenarnya tidak terpisahkan dari unsur lingkungannya sehingga unsur lingkungan ini harus dijaga agar mempunyai hubungan yang harmonis. Manusia, tempat tinggal, dan lingkungan merupakan merupakan satu kesatuan yang tidak dapat dipisahkan karena pada hakikatnya manusia merupakan bagian dari lingkungan. Manusia dapat dibentuk oleh tempat tinggal dan lingkungan. Sebaliknya tempat tinggal dan lingkungan akan dibentuk serta diubah oleh manusia selama manusia itu menjalani kehidupannya (Rehman, 2002). Bila kita menginginkan rumah tinggal yang islami, maka yang pertama harus diperhatikan adalah kita harus memilih lingkungan yang islami.

'Pilihlah tetangga (lihat calon tetangganya atau lingkungannya dulu) sebelum memilih rumah. Pilihlah kawan perjalanan sebelum memilih jalan dan siapkan bekal sebelum berangkat (bepergian) (HR. Al Khatib)'.

Pilihlah rumah di antara tetangga yang baik. Sebab jika tetangga dan lingkungan tidak baik, maka hidup akan merasa kurang nyaman. Bila memungkinkan lokasinya dekat dengan masjid, tidak hanya sekedar mengingatkan masuknya waktu shalat, juga dapat menunaikan shalat berjamaah, dan anak-anak terbiasa dengan suasana ibadah. Bila lingkungan yang yang baik sudah kita dapatkan barulah kita mulai memikirkan rancangan rumah tinggal yang islami.

Baiti Jannati, rumahku adalah surgaku. Demikian sabda Rasulullah SAW, yang menggambarkan betapa pentingnya peran rumah dan keluarga dalam kehidupan manusia. Yang dimaksud dengan rumah yang Islami adalah rumah 
yang dibangun semata-mata hanya untuk beribadah dan berserah diri kepada Allah. Lebih lanjut, terwujudnya rumah tinggal yang didasari nilai-nilai Islam dapat pula membentuk satu perilaku dan akhlak yang menuju kepribadian dan citra diri Islam yang dibentuk dari lingkungan tersebut.

Ciri rumah yang Islami adalah rumah yang di dalamnya selalu didirikan ibadah kepada Allah, rumah yang di dalamnya terjadi internalisasi nilai Islam secara kaffah (sempurna), rumah yang di dalamnya ada qudwah hasanah (keteladanan yang baik), rumah yang di dalamnya ditegakkannya syariat Islam, rumah yang dapat menghindarkan penghuninya dari hal-hal yang tidak Islami, dan rumah yang berperan sebagai tempat pembinaan generasi mendatang. Rumah yang Islami bukanlah rumah yang desain arsitekturnya seperti masjid atau rumah yang di dalamnya penuh dengan ornamen-ornamen Islam, seperti kaligrafi, dan lainnya. Rumah yang Islami adalah rumah yang memungkinkan penghuninya untuk saling bersilaturahmi dan berinteraksi. Sementara itu, privasi masingmasing orang juga bisa terjaga di dalamnya (Rehman, 2002). Namun, yang lebih penting rumah yang Islami adalah rumah yang tidak menutup diri dari dunia luar. Memungkinkan interaksi dan hubungan sosial dengan lingkungan sekitar dan para tetangga bisa berlangsung dengan baik. Rumah Islami juga bukan rumah yang menonjolkan kemewahan dan kekayaan. Untuk itu, maka beberapa hal yang terkait dengan konsep rumah yang islami adalah sebagai berikut :

\section{A. Adab dan aturan seorang muslim baik di dalam rumahnya maupun di lingkungan sekitar}

Adab dan aturan yang mesti diterapkan oleh seorang muslim di dalam rumahnya dan terhadap anggota keluarganya, adalah cerminan dari rahmat Allah terhadap hambaNya ini. Pengetahuan seorang muslim akan adab dan aturanaturan yang lslami dalam penataan rumahnya merupakan hal yang sangat penting bagi terciptanya rumah yang lslami. Adapun aturan-aturannya, adalah:

\section{Tentang kebersihan dan kesucian}

"Telah bersabda Rasulullah SAW, sesungguhnya Allah iu Maha Baik, Bersih mencintai kebersihan, Mulia menyenangi kemuliaan, Dermawan menyenangi kedermawanan. Bersihkanlah pekarangan kalian, jangan menyerupai orangorang yahudi"(Hadits Hasan, riwayat lmam Tirmidzi).

Kelebihan menonjol yang dimiliki oleh seorang muslim dalam dirinya, rumahnya dan lingkungannya, adalah kebersihannya. Thaharah, dalam kebiasaannya selalu dihubungkan dengan air, sehingga orang sering mengidentikkan antara kesucian dan kebersihan. Seorang muslim akan sangat memperhatikan kedua masalah tersebut, yaitu kesucian dan kebersihan, dalam waktu yang sama. Hal inilah yang menjadikan seorang muslim berbeda dan mempunyai kelebihan dibanding yang lainnya. Seorang muslim, sekaligus akan membersihkan kotoran dan mensucikan najis, menghilangkan sekaligus dua unsur, unsur lahiriah, yaitu kotoran dan unsur ma'nawiyah, yaitu najis (Sai'd, 2002).

Dalam usaha mewujudkan kebersihan, hendaklah seorang muslim memperhatikan hal-hal sebagai berikut: 
> Hendaklah seorang muslim dan anggota keluarganya, membiasakan untuk tidak membuang sesuatu, atau sampah, kecuali pada tempat yang sudah disediakan.

$>$ Hendaklah kaum wanita mengatur waku tertentu untuk mencuci pakaian dan perabotan bekas makan.

$>$ Hendaklah anggota keluarga memperhatikan barang-barang yang sering terkena debu, kemudian membersihkannya.

$>$ Hendaklah ada waktu tertentu yang telah disepakati untuk membersihkan rumah.

> Hendaklah setiap anggota keluarga mempunyai jadwal mandi tersendiri, jangan sampai selama satu minggu tidak pernah mandi. Diantara sunnah Rasulullah SAW adalah mandi dihari Jum'at, menggunakan siwak untuk membersihkan gigi, dan menyehatkan gusi.

$>$ Hendaklah penghuni rumah menata rumahnya, sehingga terbebas dari polusi udara yang tak sedap, yang membahayakan penghuni rumah, atau tetangganya. Yang paling penting untuk diperhatikan adalah kebersihan dapur, kamar mandi dan WC (Sa'id, 2002).

\section{Tentang tatacara mengatur dan menata interior rumah}

Adab seorang muslim di rumah dan di luar rumahnya harus tertib, rapi, dan enak dipandang kecuali dalam beberapa hal tertentu. Untuk merealisasikan ketertiban, kerapian dan enak dipandang, hendaklah seorang muslim memperhatikan hal-hal berikut ini:

$>$ Hendaklah semua apa yang ada dalam rumah tertata dengan rapi, dan di tempatkan pada tempatnya. Apabila kita menggunakan suatu barang, hendaklah kita letakkan kembali pada tempatnya. Adapun waktu yang tepat untuk menata dan merapikan rumah, adalah waku pagi hari.

$>$ Setiap anggota keluarga diharapkan tidak memaksakan kehendaknya sendiri dalam menata barang-barang yang ada, akan tetapi hendaklah membiasakan meletakkan suatu barang pada tempat yang sudah ditentukan.

$>$ Setiap kamar harus ditata sesuai dengan situasi dan kondisi kamar tersebut sesuai dengan sifat dan kegunaan kamar.

$>$ Semua barang yang ada diatas meja, seperti buku-buku, kertas-kertas penting, hendaklah disusun dengan baik dan rapi (Sa 'id, 2002).

\section{Tentang adab merendahkan suara, menjaga rahasia dan tidak membuat kegaduhan.}

Dimanapun suatu keluarga hidup, dia akan mempunyai tetangga, rekan sepergaulan, dan kerabat yang hidup disekitarnya, satu atau lebih. Dari sinilah ditekankan untuk memperhatikan hak-hak mereka, yaitu tidak saling mengganggu satu terhadap yang lainnya. Diantara kegaduhan yang paling mengganggu di dalam rumah, adalah suara yang keras.

Dalam rumah yang lslami, penghuninya tidak akan mendengar hal-hal yang menyakitkan, menyinggung perasaan, atau sesuatu yang mengacaukan suasana dan membuat gaduh. Begitu pula tetangganya akan merasa aman, tidak terganggu oleh kegaduhan dan tidak pernah mendengar hal-hal seperti diatas (Sa ’id, 2002). 
Memperhatikan hal diatas, hendaklah keluarga muslim memperhatikan halhal sebagai berikut:

> Apabila kaum wanita mempunyai keperluan terhadap anggota keluarganya yang lelaki, sedangkan mereka tengah menghadapi tamu, hendaklah dia mengetuk pintu sebagai pengganti dari panggilan.

$>$ Jika pintu diketuk orang, dan di rumah tersebut ada lelaki, maka merekalah yang harus menjawab ketukan pintu tersebut, jika tidak ada lelaki maka wanita dibolehkan menjawab ketukan itu dengan jawaban yang pendek serta dengan suara yang tegas, suara yang tidak menampakkan kegemulaiannya.

$>$ Apabila berbincang-bincang baik antara orang tua, atau antara anak- anak, atau antara anak dan orang dewasa, hendaklah dengan suara yang wajar. Dan hal yang mesti diperhatikan oleh anggota keluarga adalah hendaklah mereka membiasakan berkata dengan bahasa yang halus.

> Hendaklah, anggota keluarga menjauhkan hal-hal yang akan menimbulkan kegaduhan, suara yang keras, atau sesuatu yang akan menyakiti.

$>$ Jika dimungkinkan, tidak menggunakan alat yang membuat berisik, dalam memenuhi kebutuhan rumah tangga.

$>$ Jangan bersikap tidak peduli terhadap anak jika mereka menangis.

$>$ Hal yang perlu dibiasakan oleh anggota keluarga muslim adalah menjaga rahasia. Tidak semua hal yang teriadi dalam rumah mesti diceritakan oleh anggota keluarga. Hal yang paling ditekankan oleh Rasulullah SAW dalam masalah ini, adalah tidak bolehnya suami isteri menceritakan kepada orang lain, hal-hal khusus yang terjadi antara mereka berdua ( $\mathrm{Sa}$ 'id, 2002).

\section{Tentang tatacara mengatur hal-hal yang berkaitan dengan ilmu dan ibadah}

Tidak ada yang lebih penting dalam kehidupan keluarga muslim selain dari dua permasalahan ini, yaitu mengatur hal-hal yang berkaitan dengan ilmu dan ibadah. Hal yang harus menjadi perhatian utama dalam masalah ilmu adalah ilmu-ilmu yang wajib dan yang dibutuhkan ( $S a$ 'id, 2002).

\section{Tentang bersikap sederhana dalam makan, minum, berpakain dan gaya hidup}

Seorang muslim dalam makan dan minumnya dituntut untuk melaksanakan aturan yang telah Allah SWT tentukan:

$>$ Tidak boleh berlebih-lebihan.

"Makan dan minumlah, dan janganlah berlebih-lebihan".

$>$ Tidak boleh makan dan minum sesuatu yang membahayakan dirinya, apalagi yang haram.

> Hendaklah makan dan minum dengan seimbang. Rasulullah SAW bersabda, "Tidaklah seorang anak Adam dapat memenuhi suatu wadah dengan kejelekan kecuali perutnya. Cukuplah bagi anak Adam suapan makanan yang membuat tulang punggungnya tegak. Jika tidak dapat mengalahkan nafsunya, maka sebaiknya dia mengisi sepertiga untuk makannya, sepertiga untuk minumnya, dan sepertiga untuk nafasnya". (Hadits shahih riwayat lmam Ahmad, Tirmidzi dan ibnu i'iajah). 
Jangan sampai menampakkan kegemukan (sehingga terlihat lipatan-lipatan lemak pada tubuhnya). Rasulullah SAW pernah mengecam satu generasi dalam sebuah haditsnya, "Akan muncul diantara mereka orang-orang yang gendut, karena banyak makan" (HR lmam Ahmad dan Bukhari).

Menumpuk-numpuk pakaian dan barang-barang yang tidak penting pemakaiannya adalah merupakan pemborosan, serta berdampak negatif bagi jiwa. Pakaian mesti disesuaikan dengan kebutuhan kita, begitu pula barang-barang keperluan rumah.Hidup sederhana dan hemat tidak sama dengan sifat kikir. Seorang muslim dilarang bersifat kikir, dan kita tidak bisa memungkiri bahwa kebutuhan keluarga satu sama lainnya saling berbeda, begitu pula zaman pun menuntut perbedaan tersebut ( $\left.S a^{\prime} i d, 2002\right)$.

\section{Tentang tatacara menjalin hubungan yang baik dan adab bergaul}

Keluarga, lingkungan dan sekolah, adalah sumber pendidikan yang asasi dalam kehidupan manusia. Pengaruh keluarga terhadap seseorang sangat besar. Pada umumnya keluarga akan mempengaruhi seseorang dalam hal agama, akhlak dan adab pergaulannya.

Oleh sebab itu, merupakan hal yang penting sekali jika rumah yang islami berperan dalam membentuk seseorang, menyangkut adab bergaulnya dan cara berhubungan dengan masyarakat, sehingga dapat dipraktekkannya di dalam dan diluar rumah. Banyak sekali orang yang bertabiat jelek di rumahnya dan dia berusaha untuk menjadi tokoh panutan diluar rumahnya. Ada sejumlah nash yang menyebutkan bahwa pada suatu saat akan muncul generasi dimana seseorang akan mentaati isterinya di rumah tetapi durhaka terhadap ibunya. Berbuat baik terhadap temannnya tetapi durhaka kepada kedua orang tuannya (Sa 'id, 2002).

Tolak ukur berbuat baik adalah baiknya hubungan seseorang dengan orang yang paling dekat. Orang terbaik diantara kalian adalah yang paling baik kepada keluarganya. Dalam salah satu hadits, Rasulullah SAW bersabda, "Ibumu, ibumu, ibumu kemudian ayahmu, kemudian yang dibawahmu". (HR Bukhari dan Muslim).

Oleh sebab itu di dalam rumah islami harus diterapkan adab pergaulan dan hubungan yang baik. Adab terhadap orang tua adalah dengan menghormatinya, taat kepada keduanya, berbuat baik dan mengistimewakan keduanya. Hal ini harus benar-benar diperhatikan dan dijaga (Sa'id, 2002).

Hubungan yang harmonis antara suami dan isteri, bermuamalah dengan penuh kelembutan tidak disertai kekasaran, tidak berteriak-teriak, menjauhkan diri dari pertentangan dan perselisihan, isteri taat pada suaminya, memperhatikan dan menjaga anak-anaknya dengan penuh kasih sayang dan keceriaan, mendidiknya dengan baik dalam masalah yang berhubungan dengan agama maupun dunia, semuanya adalah hal-hal yang teramat penting untuk diperhatikan.

\section{Tentang memperhatikan kesehatan dan olahraga}

Keluarga, lingkungan dan sekolah, adalah sumber pendidikan yang asasi dalam kehidupan manusia. Pengaruh keluarga terhadap seseorang sangat besar. 
Pada umumnya keluarga akan mempengaruhi seseorang dalam hal agama, akhlak dan, adab pergaulannya.

Islam sangat memperhatikan masalah kekuatan, apalagi masalah kesehatan. Oleh sebab itu memperhatikan masalah olahraga dan kesehatan merupakan bagian dari pembinaan rumah lslami, dan merupakan aturan yang mesti dilakanakan dalam rumah. Dalam sebuah hadist yang diriwayatkan oleh Imam Bukhari dijelaskan, "Ada dua kenikmatan yang dilupakan oleh kebanyakan orang, kesehatan dan waktu luang”. (HR Bukhari)

Melihat keterangan diatas maka pengaturan masalah kesehatan sangat penting, dengan memperhatikan masalah pengobatan, makanan, kebersihan, udara yang masuk ke dalam rumah, ventilasi sinar matahari yang masuk, dan mencegah masuknya penyakit dengan tindakan prefentif terhadap sebab-sebab penyakit.

Sebagai penghuni rumah kita pun harus selalu memperhatikan masalah kelembaban udara sekitar kita sehingga tidak menimbulkan bau yang kurang sedap, ventilasi udara yang cukup sehingga udara segar dapat masuk mengusir udara yang kotor. Begitu pula fentilasi sinar matahari, dan yang paling penting adalah selalu menjaga kebersihannya (Sa'id, 2002).

Masalah pengobatan pun harus diperhatikan, apabila salah seorang anggota keluarga kita terserang penyakit. Perhatian terhadap makanan pun sama pentingnya, dengan memilih makanan yang bermanfaat dan tidak menimbulkan efek negatif. Setiap anggota keluarga diharapkan membiasakan berolahraga sehingga tiada satu hari pun berlalu tanpa olahraga, apapun bentuknya, jalan kaki, jogging, lari ditempat, senam, lompat tali, dst. Pada pokoknya setiap anggota keluarga mesti punya waktu untuk berolahraga. Alangkah baiknya jika program olahraga tersebut selalu dipadukan dengan dzikir dan do'a.

\section{Tentang melindungi rumah dan anggota keluarga dari akhlaq, perilaku menyimpang dan ganjil, serta menjauhkan mereka dari hal-hal yang haram, makruh, dan membahayakan}

Allah SWT berfirman, "Hai orang-orang yang beriman, peliharalah dirimu dan keluargamu dari api neraka". (QS. At-Tahriim:6)

Seorang muslim selamanya akan selalu aktif melaksanakan tuntutan-tuntutan agama, begitu pula terhadap keluarganya dan berusaha untuk menjauhkan dirinya dan keluarganya dari hal-hal yang dilarang oleh agama.

Pada bab terdahulu dijelaskan bahwa masalah yang berkaitan dengan ilmu dan ibadah perlu dirumuskan pengaturannya dalam rumah seorang muslim. Adapun hal-hal yang harus dijauhkan dari rumah yang lslami, yaitu hal-hal yang bertentangan etika dan akhlaq, apalagi hal-hal yang bertentangan dengan amalan-amalan sunnah, wajib, dan fardhu. Harus diusahakan jangan sampai terjatuh ke dalam hal-hal yang makruh dan haram (Sa'id, 2002).

Kaum muslimin sudah terbiasa memandang apa yang ada di dalam rumah sebagai aurat yang harus dijaga dari pandangan orang lain. Diantara mereka ada yang selalu menjaga agar orang luar tidak melihat apa yang ada di dalam rumahnya, dan selalu berhati-hati dalam keluar untuk melakukan pekeriaan rumah tangganya, seperti menjemur pakaian atau mengambil jemuran. 
Perlu diperhatikan, ada sebagian dari pakaian kita yang tidak layak untuk dilihat orang lain, seperti pakaian dalam, karena hal tersebut akan mengganggu perasaan, sehingga menimbulkan perasaan yang kurang enak, disamping sebenarnya menyalahi etika umum. Hal yang harus diperhatikan juga oleh anggota keluarga ialah, jangan sampai ada pakaian wanita diruang tamu kita, karena jika terlihat oleh tamu akan mengganggunya, disamping memang menyalahi etika umum. Demikian pula ruang tamu jangan sampai acak-acakan, tidak tertata dengan rapi (Sa'id, 2002).

Kelakuan dan kata-kata yang ganjil jangan sampai dipraktekkan oleh anggota keluarga yang lslami, baik dalam keadaaan sendiri atau bersama orang lain. Hal yang harus dijaga dalam keluarga yang islami adalah menjaga aurat, jangan sampai menampakkan aurat di hadapan orang lain sekalipun anak kecil. Bahkan semenjak usia dini hendaklah anak-anak dibiasakan untuk menutup auratnya. Hal yang mesti ditanamkan semenjak kecil terhadap anak perempuan adalah jangan menampakkan diri di hadapan laki-laki.

Hal yang perlu dihindarkan dari dalam rumah adalah gambar-gambar hewan dan patung-patung, serta semua hal yang dimakruhkan dan diharamkan oleh para ulama, walaupun dalam hal ini terdapat perbedaan pendapat. Hal lain yang perlu dihindarkan dari rumah lslami adalah, apa-apa yang termasuk dalam kategori makruh dan haram, seperti kebanyakan acara-acara radio dan televisi, atau pemutaran video dan tape dengan memutar kaset-kaset yang tidak berfaedah (Sa'id, 2002).

Seorang muslim tidak boleh lengah dan tidak mengetahui hal yang baik dan hal yang buruk. Hal baik yang harus dipraktekkan dan yang buruk harus dijauhkan.

Anggota keluarga harus dibiasakan menjaga rahasia mereka, dan mejaga gerak-gerik mereka dari hal-hal yang jelek, menjaga keamanan rumah mereka dan keamanan anak-anak mereka. Tersiarnya rahasia rumah tangga adalah merupakan langkah awal datangnya petaka. Oleh sebab itu semua anggota keluarga harus dibiasakan tidak menceritakan tentang masalah yang terjadi dalam keluarga kecuali hal itu member manfaat dan maslahat.

Tersiarnya rahasia keluarga ini disamping akan menimbulkan petaka duniawi juga bertentangan dengan syari'at dan membahayakan moral. Oleh sebab itu tidak layak seorang suami atau isteri menceritakan rahasia kamar mereka, atau menceritakan perbuatan yang bertentangan dengan adab dan etika (Sa'id, 2002).

Pintu rumah pun sebaiknya dibiasakan tertutup dan diamankan dari para pencuri dan mata-mata serta semua hal yang mengancam keamanan rumah, atau semua hal yang mencurigakan. Perhatian terhadap hal-hal yang akan mengakibatkan kebakaran pun mesti ditekankan, baik barang-barang yang ada di dalam rumah ataupun yang ada di luar rumah. Perlu juga diperhatikan untuk tidak tidur ditempat yang mengakibatkan kita jatuh, serta memperhatikan anakanak dalam bermainnya, jangan sampai bermain di tempat yang berbahaya dan mencelakakan mereka. Juga tidak pantas jika kita meletakkan barang-barang yang berbahaya dihadapan anak-anak, baik berupa obat-obann maupun bendabenda tajam, atau barang-barang yang mudah pecah. 
Demikianlah, rumah yang lslami harus dihindarkan dari semua pemandangan yang menyalahi syariat lslam atau keamanan.

Hal yang penting untuk diperhatikan dalam rumah lslami ialah membedakan antara dua status kemahraman wanita, yaitu antara wanita yang haram dinikahi untuk selamanya dan wanita yang haram dinikahi hanya untuk sementara. Terhadap wanita yang bukan mahram dilarang menjabat tangannya, menyentuhnya, berduaan dengannya, membuka aurat, dan bersolek dihadapannya. Sungguh ada sebagian lingkungan yang menyepelekan masalah ini. Kepada mereka harus dikenalkan hukum-hukum syari'ah dan ditekankan agar senantiasa terikat dengan hukum tersebut (Sa'id, 2002).

Ada sebagian orang yang sudah berkeluarga, tetapi masih hidup bersama dengan kerabatnya yang lain. Dalam keadaan seperti ini perlu adanya penegasan bahwa isteri saudara kita adalah bukan mahram, dia tidak boleh menampakan dirinya tanpa pakaian yang menutupi aurat secara sempurna dihadapan saudara laki-laki suaminya, dan tidak boleh bersalaman atau berduaan. Begitu pula sebaliknya isteri saudara lelakinya tidak boleh menampakkan diri dihadapan suami saudaranya perempuannya, kecuali dengan hijab yang syar'i, mereka dilarang untuk saling berjabat tangan dan berduaan ( $S a$ 'id, 2002).

\section{Tentang berbuat baik kepada tetangga, menghormati tamu dan bersilatuhrahmi}

Rumah seorang muslim adalah rumah yang akan menghormati tamunya. Bertamu ke rumah seseorang tidak dibenarkan kecuali atas kesepakatan keluarga yang akan kita kunjungi, karena beban menghormati tamu adalah menjadi beban semua anggota keluarga. Maka syarat bertamu adalah ridhanya mereka menerima kita sebagai tamu.

Diantara adab islami dalam bertamu adalah tidak boleh memberatkan orang yang kita kunjungi agar dia menjamu kita sebagai tamu, karena hal demikian adalah pintu menuju kebakhilan. Jika menghormat tamu selalu dikaitkan dengan menjamu, mungkin ikhwan dan orang yang kita kunjungi tidak akan mampu membiayainya (Sa'id, 2002).

Maka menghormati tamu tanpa membebani keluarga yang lain dengan beban materi dan tidak menyusahkan adalah salah satu adab seorang muslim. Seorang muslim harus senantiassa menyiapkan dirinya, rumahnya dan keluarganya untuk menerima tamu dan menghormatinya. Dan para tamu harus memahami kemampuan orang yang dikunjunginya dalam menghormati tamunya. Kalau seandainya ada sesuatu yang memberatkan, atau melelahkan mereka dengan kedatangannya maka dia harus mengerti dan segera berpamitan dengan cara yang sebijaksana mungkin. Jika semua rumah muslimin siap untuk menerima tamunya, maka para tamu dengan keinginannya tinggal memilih rumah mana yang akan dia kunjungi.

Sepantasnya mereka yang masih bujangan menginap tamunya dan mereka yang sudah berkeluarga mengajak makan para tamunya ( $S a$ 'id, 2002).

Seperti halnya rumah lslami adalah rumah yang siap menghormati tamunya, maka rumah yang lslami pun harus menjadi salah satu sarana untuk bersilaturahmi, yaitu dengan saling mengunjungi satu sama lain, menegakkan 
hak silaturahmi itu sendiri diantara keluarga dan kerabat dengan saling menghormati, saling memberi hadiah, dan saling berkirim surat. Juga tidak lupa menyambut dengan sambutan yang baik dan penuh rasa hormat.

Adapun tetangga rumah, mereka harus merasakan damai dengan kehadiran rumah islami ini, mendapatkan perhatian yang penuh dan menyukai mereka. Rumah lslami harus dapat mencegah hal-hal yang menyakitkan mereka, dan mengetahui hak-hak mereka.

Diantara hak yang harus ditunaikan oleh anggota keluarga rumah lslami terhadap tetanganya ialah memenuhi hak-hak peristiwa tertentu (huququl munasabah), baik peristiwa kegembiraan atau kesedihan. Diantara hal penting yang harus diperhatikan dalam menjaga keharmonisan hubungan dengan tetangga adalah menjaga anak-anak jangan sampai berkelahi dengan anak tetangga. Bila terjadi perkelahian maka anak tetanggalah yang harus dianggap sebagai pihak yang benar (Sa'id, 2002).

Hal lain yang perlu mendapat perhatian adalah menghindarkan kebisingan dari mereka. Usahakan jangan sampai mereka mendengar sesuatu yang menggangu dan menyakitkan, baik itu pertengkaran atau karena suara yang muncul dari rumah. Jika mereka tinggal dalam satu apartemen, penuhilah hak mereka dengan sempurna, koreksi diri sendiri saja dan usahakan tidak mendzolimi mereka (Sa'id, 2002).

\section{Tentang menjaga adab keluar masuk rumah}

Hal pertama yang harus diperhatikan oleh seorang muslim dan muslimah dalam keluar masuk rumah adalah sunnah-sunnah yang berkaitan dengan masalah tersebut, seperti do'a, kaki mana yang mesti didahulukan, dan memberi salam kepada keluarga. Diantara sunnah yang ada ialah mendahulukan kaki kiri apabila keluar. Memberi salam kepada keluarga, baik ketika masuk atau keluar rumah.

Sebelum keluar rumah hendaklah menentukan niat, arah tujuan dan mengoreksi diri, serta memeriksa barang bawaannya. 1steri pun hendaknya membantu memeriksa bawaan suaminya (Sa 'id, 2002).

Kaum wanita, apabila hendak keluar rumah hendaklah memperhatikan halhal berikut tidak tercium bau parfum, merapikan hijab dan jilbabnya sampai tidak terlihat auratnya karena tertiup angin atau salah pakai. Ada sebagian wanita yang biasa berjalan menggunakan sepatu sampai terdengar oleh orang lain dan mengundang perhatian orang untuk melihatnya. Perilaku ini bertentangan dengan adab lslami. Wanita jahiliyah dahulu jika berjalan suka menghentak-hentakkan kakinya supaya bunyi gelang kakinya terdengar. Perilaku seperti ini diharamkan bagi wanita muslimah. Allah SWT berfirman, "Dan janganlah mereka memukulkan kakinya agar diketahui perhiasan yang mereka sembunyikan”. (QS. An-Nuur: 31)

\section{B. Merancang Rumah Islami yang Ideal}


Untuk merancang sebuah rumah islami, ada beberapa hal esensial yang perlu diperhatikan. Sehingga didapat sebuah desain rumah islami yang ideal, tidak hanya sekedar dekoratif saja. Hal-hal tersebut antara lain :

1. Desain rumah hendaknya tidak ditujukan untuk menunjukkan status sosial seseorang (kedudukan atau jabatan). Indah tapi tidak berlebihan atau glamour. Ramah terhadap lingkungan dan hubungan dengan tetangga terjaga dengan baik.

2. Dinding atau pagar sebaiknya tidak terlalu tinggi, sehingga membuat rumah terlingkupi dan terkesan sebagai benteng yang memutuskan hubungan dengan tetangga. Dengan catatan masih memenuhi fungsinya sebagai pengaman.

3. Pintu utama dan teras usahakan tidak diletakkan secara tegak lurus dengan ruang tamu. Sebaiknya disamping rumah. Hal ini dimaksudkan agar ketika tuan rumah membuka pintu, seorang tamu tidak langsung melihat isi rumah melainkan hanya sebagian kecil. Selain itu desain juga menjaga agar ketika ada seorang tamu dan tuan rumah dalam keadaan tidak siap menerima tamu (tidak berjilbab), aurat tuan rumah akan tetap terjaga. Hal ini juga menjaga dari pandangan orang iseng yang sambil lewat melonggok kedalam rumah (Rehman, 2002).

4. Ruang tamu hendaknya tidak bersambung dengan ruang keluarga dan ruang ruang lain dalam rumah sehingga aktivitas penghuni tidak bisa diketahui oleh tamu. Ruang tamu harus benar-benar dirancang supaya penghuni tidak merasa terganggu aktivitasnya dengan kedatangan tamu.

5. Kamar mandi usahakan mudah perawatannya sehingga kebersihannya tetap terjaga. Pilih bahan yang mudah dibersihkan dan tidak mudah ditumbuhi jamur atau lumut

6. Letak toilet sebaiknya tidak menghadap kiblat, usahakan menghadap utara atau selatan.

7. Sebaiknya meminimalkan hiasan berupa patung dan gambar manusia atau binatang akan menghalangi malaikat Rahmat untuk masuk kedalam rumah.

8. Sediakan sebuah ruang untuk tempat beribadah (mushola, untuk shalat-shalat sunnah) sekaligus sebagai tempat pembinaan bagi seluruh anggota keluarga. Ruang yang akan memberi ruh dan sumber cahaya ilahi bagi keluarga (Rehman, 2002).

Secara praktisnya berikut hal-hal yang harus diperhatikan dalam mendesain rumah yang Islami:

1. Tidak perlu meminta petunjuk dari orang pintar/paranormal untuk menentukan hari dan tanggal yang baik dalam membuat rumah karena semua hari dan tanggal itu baik disisi Allah. Mempercayai hal-hal yang berbau takhayul bisa membuat kita jatuh dalam perbuatan syirik.

2. Rumah adalah kehormatan dan rahasia, maka jangan membuat rumah yang banyak kaca tembus pandangnya hingga memungkinkan orang luar bisa melihat ke dalam rumah kita. Hal ini untuk menjaga rahasia dan aurat keluarga kita.

3. Akan lebih baik jika kita membuat rumah dengan kamar yang banyak sehingga kita bisa memisahkan kamar anak laki-laki dan perempuan. Juga 
jika sewaktu-waktu ada tamu yang ingin bermalam, kita bisa membantunya menyediakan kamar. Tapi hendaknya kamar untuk tamu terpisah dari ruang keluarga sehingga tidak memungkinkan tamu bisa melihat dengan bebas ruang keluarga.

4. WC atau toilet hendaknya dibuat tidak menghadap/membelakangi kiblat. Meskipun ada khilaf, jika tertutup dengan bangunan maka diperbolehkan. Tapi untuk kehati-hatian lebih baik menghadap ke arah lain.

5. Jangan meninggikan bangunan, karena itu termasuk tanda-tanda hari kiamat sebagaimana disabdakan oleh Rasulullah shalallahu'alaihi wasallam ketika ditanya oleh malaikat jibril.

\section{Prinsip-Prinsip Rumah Islami}

Prinsip-prinsip berikut menjadi landasan utama perencanaan dan pembangunan rumah islami, yaitu:

1. Prinsip Tauhid (kepercayaan tentang ke-Esa-an Tuhan)

Allah adalah satu dan tidak ada sekutu dalam penciptaan dunia. Allah adalah pelaksana semua urusan di dunia ini dan semuanya tiada pencipta dan pemberi. Semua maujud dari yang besar hingga yang kecil, adalah ciptaan Allah.

Bila saat ini kita berencana membangun rumah, maka harus disadari bahwa hal ini hanya karena kekuasaan Allah, sehingga kita memiliki kemampuan untuk membangun sebuah rumah. Harus diingat pula bahwa kita akan membangun rumah di atas lahan milik Allah, menggunakan bahanbahan ciptaan Allah, mulai dari batu untuk pondasi, tanah (bata) untuk dinding, kayu untuk atap dan pintu. Maka sadarilah bahwa kita membangun rumah, semata-mata hanya karena kekuasaan dan pemberian Allah. Membangun rumah semata-mata hanya untuk beribadah dan berserah diri kepada Allah (Haider, 2002).

2. Prinsip Rububiyah (mensyukuri rahmat dan rejeki-Nya)

Sungguh suatu rahmat yang luar biasa bila saat ini kita diberi keluasan rezeki, hingga kita dapat membangun sebuah rumah. Betapa banyak saudarasaudara kita yang kurang beruntung sehingga mereka tidak memiliki kemampuan untuk memiliki sebuah rumah. Sudah sepantasnya kita bersyukur atas rahmat dan rezeki yang telah diberikan kepada kita. Salah satu ungkapan rasa syukur kita adalah dengan menggunakan rezeki dengan bijak, tidak berlebih-lebihan tidak pula kikir. Dalam membangun rumah, kita harus menggunakan sumber daya secermat mungkin, sehingga tidak ada yang mubazir. Namun jangan pula pelit (terlalu irit) yang dapat berpengaruh terhadap kekuatan bangunan (Haider, 2002).

3. Prinsip Khilafah (bertanggung jawab terhadap diri dan dunianya)

Allah SWT menciptakan manusia di muka bumi agar manusia dapat menjadi khalifah di muka bumi tersebut. Yang dimaksud dengan khalifah 
ialah bahwa manusia diciptakan untuk menjadi penguasa yang mengatur apaapa yang ada di bumi, seperti tumbuhannya, hewannya, hutannya, airnya, sungainya, gunungnya, lautnya, perikanannya dan seyogyanya manusia harus mampu memanfaatkan segala apa yang ada di bumi untuk kemaslahatannya. Jika manusia telah mampu menjalankan itu semuanya maka sunatullah yang menjadikan manusia sebagai khalifah di bumi benar-benar dijalankan dengan baik oleh manusia tersebut, terutama manusia yang beriman kepada Allah SWT dan Rasulullah SWT.

Ketika memerankan fungsinya sebagai khalifah Allah di muka bumi, ada dua peranan penting yang diamanahkan dan dilaksanakan manusia sampai hari kiamat. Pertama, memakmurkan bumi (al 'imarah). Kedua, memelihara bumi dari upaya-upaya perusakan yang datang dari pihak manapun (ar ri'ayah).

Manusia mempunyai kewajiban kolektif yang dibebankan Allah SWT. Manusia harus mengeksplorasi kekayaan bumi bagi kemanfaatan seluasluasnya umat manusia. Maka sepatutnyalah hasil eksplorasi itu dapat dinikmati secara adil dan merata, dengan tetap menjaga kekayaan agar tidak punah. Sehingga generasi selanjutnya dapat melanjutkan eksplorasi itu.

Melihara bumi dalam arti luas termasuk juga memelihara akidah dan akhlak manusianya sebagai SDM (sumber daya manusia). Memelihara dari kebiasaan jahiliyah, yaitu merusak dan menghancurkan alam demi kepentingan sesaat. Karena sumber daya manusia yang rusak akan sangatlah potensial merusak alam. Oleh karena itu, hal semacam itu perlu dihindari.

Setiap jengkal lahan yang kita miliki adalah amanah, kita akan dimintai pertanggungjawaban atas apa yang telah dititipkan kepada kita. Gunakan dan peliharalah lahan yang kita miliki secara optimal namun tidak melanggar hak yang lainnya, seperti hak lingkungan, tetangga, alam juga mahluk hidup yang lainnya (Haider, 2002).

4. Prinsip Tazkiyah (memelihara hubungan dengan Tuhan, sesamanya dan alam lingkungannya)

Habluminannas dan habuminal alam dalam rangka habluminallah. Ketiganya sejalan dan tidak untuk dipertentangkan. Orang yang mengabaikan habluminannas dan habluminal alam selain mendapatkan murka dari Allah dan konsekuensi di akhirat, juga akan menerima konsekuensi dari sesama manusia dan dari alam yaitu berupa perlakuan atau sanksi atau hukuman dari aturan/hukum atau norma masyarakat di mana ia berada. Bencana alam juga sering terjadi akibat manusia merusak alam, seperti penggundulan hutan yang mengakibatkan erosi/longsor dan banjir.

Habluminallah, manusia diciptakan oleh Allah untuk mengabdi kepadaNya. Allah memerintahkan manusia untuk menyembah hanya kepada Allah, dan beribadah kepadaNya.

Habluminannas, Allah memerintahkan manusia untuk saling menyayangi dan berbuat baik satu dengan yang lainya.

Habluminal alam, Allah memerintahkan manusia untuk tidak membuat kerusakan di muka bumi, tetapi harus memakmurkan bumi, dan memelihara bumi dari upaya perusakan dari pihak manapun (Haider, 2002). 


\section{Simpulan}

Upaya merangkum dan meringkas pemikiran para ahli ternyata membawa kita pada kesimpulan bahwa memandang rumah Islami ibarat memandang sebuah benda terbungkus rapi. Yang dibungkus lebih esensi dari pembungkusnya atau isinya lebih penting dari kulitnya, entah pembungkus itu wujudnya adalah rumah petak $3 m \times 3 m$ atau rumah mewah bak istana yang lengkap fasilitasnya. Artinya pola pikir dan tingkah laku yang Islami dari penghuninya, itulah yang lebih penting dari pada desain atau arsitektur rumahnya. Dengan demikian umat Islam dari semua kalangan dapat mewujudkan rumah Islami mulai dari hatinya, jika sudah, barulah memperindah tempat tinggalnya. Kalaupun ada keluarga yang mampu justru dari desain rumahnya yang Islami agar dapat membentuk kepribadian penghuninya.

Hanya saja, konsep desain rumah kini mengalami evolusi. Ukuran rumah tidak lagi standar sebagaimana dijelaskan di atas namun mengecil mengikuti tingkat ekonomi keluarga. Bahkan, di kota-kota besar, dengan terbatasnya lahan dan mahalnya biaya membangun rumah, membuat konsep rumah yang Islami menjadi sulit. Dalam lingkungan seperti ini privasi menjadi hal yang sulit terpenuhi apalagi jika jumlah anggota keluarga cukup banyak. Tingkat stress menjadi sangat tinggi. Selain itu, ada kecenderungan bahwa rumah sekarang menjadikan penghuninya semakin individualis dan asosial. Hal ini ditandai dengan makin kecil dan simplenya ruang tamu dan penggunaan pagar yang tinggi dengan alasan keamaan. Adalah menjadi tantangan bagi kaum terpelajar dan menengah muslim untuk hidup dalam lingkungan yang Islami termasuk memiliki rumah yang menjamin privasi, kenyamanan sekaligus bisa menjadi wahana bersilaturrahim dengan lingkungan sekitar. Lingkungan yang Islami akan menjadi modal bagi pembentuk masyarakat Islam demi terwujudnya peradaban dan kejayaan Islam.

\section{Daftar Pustaka}

Campo, J. E. 1991. The Other Side of Paradise. South Carolina: University of South Carolina Press.

Faroqhi, S. 2002. Men of Modest Substance. New York: Cambrigde University Press.

Haider, S. G. 2002. On What Makes Architecture Islamic : Some Reflections and a Proposal. London: RoutledgeCurzon

Haider, S. G. 2002. Understanding Islamic Architecture. Jakarta.

Kusmayana, Ali. 2009. Merencanakan, Merancang dan Membangun Rumah Tinggal Islami, diakses dari http://mejagambar.wordpress.com/ pada tanggal 29 April 2011.

Nunik Junara dan Yulia Eka Putrie. 2009. Rumah Ramah Lingkungan.UIN Press. Malang.

Omer, Spahic. 2004. Islamic Built Environtment. Malaysia.

Rehman, A. 2002. The Grand Tradition of Islamic Architecture. London: RoutledgeCurzon. 
Sa'id, Syaikh. 2002. Tatanan Rumah Islami. Robbani Press: Bandung. 